\title{
Nutrient and Chemical Properties of Aging Golf Course Putting Greens as Impacted by Soil Depth and Mat Development
}

\author{
Ty A. McClellan, Roch E. Gaussoin, Robert C. Shearman', \\ Charles S. Wortmann, Martha Mamo, and Garald L. Horst \\ Department of Agronomy and Horticulture, University of Nebraska-Lincoln, \\ 377 Plant Science, Lincoln, NE 68583-0724
}

\author{
David B. Marx \\ Department of Statistics, University of Nebraska, Lincoln, NE 68583-0963
}

Additional index words. Agrostis, turfgrass, rootzone, establishment

\begin{abstract}
Nutrient and chemical changes in turfgrass sand-based root zones are not well understood. This study was conducted to characterize nutrient and chemical properties in putting greens influenced by root zone mixture and establishment treatment, putting green age, and soil depth. Putting greens were constructed and established with Agrostis stolonifera $\mathrm{L}$. in sequential years from 1997 to 2000 . Treatments included root zone mixtures of 80:20 (v:v) sand and sphagnum peat and 80:15:5 (v:v:v) sand, sphagnum peat, and soil, and accelerated versus controlled establishment. In the establishment year, the accelerated treatment received 2.6-, 3.0-, and 2.6-fold more nitrogen, phosphorus, and potassium, respectively, than the controlled treatment. Soil samples were taken in Fall 2001, Spring 2004, and Summer 2004 and were analyzed for nutrient and chemical properties such as $\mathrm{pH}$, cation exchange capacity (CEC), organic matter (OM), total soluble salts (TSS), and 12 nutrients. The root zone mixture and establishment treatments had minimal effects on most nutrient and chemical properties with the exception of phosphorus and $\mathrm{pH}$. Cation exchange capacity, OM, TSS, and all nutrients decreased with soil depth, whereas soil $\mathrm{pH}$ increased. The putting green age $\times$ soil depth interaction was significant for many of the nutrient and chemical properties, but separating soil samples into mat and original root zone instead of predetermined soil sampling depths eliminated most of these interactions. The mat layer had higher CEC and $O M$ values and nutrient concentrations and lower $\mathrm{pH}$ values than the original root zone mixture.
\end{abstract}

Proper nutrient management in the root zone is important for maintaining a healthy turf (Happ, 1995). Chemical properties such as $\mathrm{pH}$ and cation exchange capacity (CEC) of the root zone influence availability of essential nutrients and impact turfgrass use, maintenance, and performance. Inadequate or excessive soil nutrient levels can lead to problems in turfgrass health, vigor, and quality (Beard, 1973; Turner and Hummel, 1992).

Putting greens comprise $\approx 1.6 \%$ of the total golf course area (Beard, 2002) but are the most trafficked and intensively managed

\footnotetext{
Received for publication 26 Sept. 2008. Accepted for publication 4 Jan. 2009.

We gratefully acknowledge the financial support provided by the U.S. Golf Association, the Environmental Institute for Golf, and the Nebraska Turfgrass Association. Special appreciation is also extended to Leonard Wit and the entire staff at the UNL John Seaton Anderson Turfgrass Research Facility for construction and maintenance of these field plots.

${ }^{1}$ To whom reprint requests should be addressed; e-mail rshearman1@unl.edu.
}

portion of the golf course (Witteveen and Bavier, 1998). Golf course putting green construction techniques typically use sandbased root zones to maintain desirable physical characteristics such as resistance to compaction and adequate saturated hydraulic conductivity (Beard, 2002; Bigelow et al., 2001; Callahan et al., 1997, 2001; Moore, 2000; Sartain and Brown, 1998). The most widely accepted and most specialized method of putting green construction is the U.S. Golf Association (USGA) specification putting green (Beard, 2002; Moore, 2000; USGA Green Section Staff, 1993). A second method of putting green construction, although not as common and less specialized than the USGA method, is the University of California specification putting green (Beard, 2002; Davis et al., 1990; Moore, 2000). Whereas these two construction methods differ considerably, both are based on extensive evaluations of soil physical properties to ensure optimum turfgrass performance and putting green playability. Both USGA and California specification putting green root zones exhibit high macroporosity and are prone to nutrient leaching (Beard, 2002; Bigelow et al., 2001; Callahan et al., 1997,
2001; Sartain and Brown, 1998; Turgeon, 1999; Waddington, 1992). Sand-based root zones are generally low in organic matter, silt, and clay content that are important for water and nutrient retention (Alexander, 1977; Beard, 1973; Bigelow et al., 2001; Callahan et al., 2001). Retention of nutrients in sand-based putting green root zones is especially difficult during the first year of establishment (Carrow et al., 2001; Guertal, 2008).

Putting greens are dynamic with chemical, physical, and biological changes occurring with time (Carrow, 2004; Curtis and Pulis, 2001; Habeck and Christians, 2000; Kerek et al., 2002; Lewis, 2005; Murphy et al., 1993). Organic matter begins to accumulate and contribute to the loss of macropore space in the root zone, soon after turfgrass establishment occurs on sand-based root zones (Carrow, 1996; Curtis and Pulis, 2001, Davis et al., 1990; Duble, 1996; Habeck and Christians, 2000). Loss of macropore space results in reduced infiltration and percolation rates, increased waterholding capacity, decreased leaching potential, improved CEC, and increased nutrient retention. As these changes occur, the root zone begins to stabilize in terms of nutrient retention and capacity to supply the nutrient needs of a mature turfgrass stand. According to Carrow et al. (2001), the timeframe for a root zone to mature (i.e., achieve nutrient stabilization) varies but generally requires between 6 and 12 months.

McClellan et al. (2007) investigated 16 nutrient and chemical properties in USGAspecification putting green root zones from the grow-in year through 7 years after establishment. Results from this study showed that many of the nutrients applied during putting green establishment were not retained in the root zone beyond the grow-in year, but in Years 2 and 3 after establishment, nutrient levels in the root zone generally began to increase. Sampling depth effects were not investigated in their study.

Mat layer development is primarily responsible for temporal changes in physical properties of putting green root zones, whereas the underlying original root zone remains relatively unchanged in regard to its physical characteristics (Curtis and Pulis, 2001; Gibbs, 2001; Murphy, 2003). Less is known of mat layer effect on chemical characteristics of putting green root zones. Because mat is high in organic matter content, it leads to enhanced CEC and nutrient retention in sand-based root zones (Beard, 1973; Bigelow et al., 2001; Callahan et al., 2001; Turgeon, 1999). McClellan et al. (2007) observed but did not measure mat development and speculated that mat might have contributed to increased nutrient retention near the putting green surface, particularly as putting greens aged.

Although these studies provide insight on the dynamics of several nutrient and chemical properties in sand-based putting greens, a better understanding of nutrient dynamics in these root zones is needed to improve turfgrass soil fertility recommendations and other 
management practices for improved putting surfaces. This study was initiated to characterize nutrient and chemical properties of putting greens as impacted by 1) root zone mixture and establishment treatments; 2) putting green age; and 3) soil profile depth.

\section{Materials and Methods}

Research was conducted at the University of Nebraska John Seaton Anderson Turfgrass Research Facility located near Mead, NE (long. $41^{\circ} 11^{\prime} \mathrm{N}$, lat. $96^{\circ} 28^{\prime} \mathrm{W}$ ). Four experimental putting greens were constructed in sequential years from 1997 to 2000 following USGA specifications (USGA Green Section Staff, 1993). Treatments included two root zone mixtures - 80:20 (v:v) sand and sphagnum peat mixture and an 80:15:5 (v:v:v) sand, sphagnum peat, and soil (Tomek silty clay loam, fine smectitic, mesic Pachic Argiudoll) in a complete factorial with two establishment year nutritional programsaccelerated and controlled. Establishment treatments, both accelerated and controlled, were based on recommendations gathered by surveying 12 golf course superintendents and a USGA agronomist, all of whom had recent experience in establishing sand-based root zone putting greens. Their recommendations for establishment treatments can be found in Table 1. The accelerated establishment treatment included high nutrient inputs and was intended to decrease the time for turfgrass cover development and readiness for play. The controlled establishment treatment was agronomically sound based on meeting turfgrass nutritional requirements (R.E. Gaussoin and R.C. Shearman, personal communication).

All root zone materials were tested by Hummel \& Co, Inc. (Trumansburg, NY) and met USGA specifications for putting green construction (USGA Green Section Staff, 1993). Calcareous sand, which typically exhibits an alkaline $\mathrm{pH}$ of 8.2 or greater (St. John and Christians, 2002) and are commonly found in this region, was used to construct the greens. Individual plots within each putting green measured $4.5 \mathrm{~m} \times 8.5 \mathrm{~m}$ and were separated by treated wood partitions. The experimental design was four experimental putting greens constructed in 4 sequential years representing the first fac- tor. Each green was a split-split plot with main plot factors being root zone mixtures and establishment treatments designed as a randomized complete block with three replications. Treatment design was a 2 (root zone mixtures) $\times 2$ (establishment treatments) factorial. The subplot factor was time (putting green age) and the subsubplot factor was soil sampling depth. The first putting green was constructed in late Summer 1996. The root zones were allowed to settle over the winter and were seeded 30 May 1997. The same timing and procedures were used for construction and seeding of subsequent greens in 1998, 1999, and 2000. All plots were seeded with 'Providence' creeping bentgrass (Agrostis stolonifera L.) at 7.5 $\mathrm{g} \cdot \mathrm{m}^{-2}$.

Preplant fertilizer was tilled into the upper $8.0 \mathrm{~cm}$ of the root zone before seeding. The elemental analyses for preplant fertilizers were $16 \mathrm{~N}-11 \mathrm{P}-10 \mathrm{~K}, 15 \mathrm{~N}-0 \mathrm{P}-24 \mathrm{~K}, 38 \mathrm{~N}-$ $0 \mathrm{P}-0 \mathrm{~K}$, and a micronutrient fertilizer of $12 \mathrm{Mg}-9 \mathrm{~S}-0.5 \mathrm{Cu}-8 \mathrm{Fe}-3 \mathrm{Mn}-1 \mathrm{Zn}$. Two weeks after seedling emergence, the accelerated establishment treatment received fertilizer applications weekly at a full rate, whereas the controlled establishment treatment received applications biweekly at a half-rate. Postplant fertilizers were applied during the growing season and had an elemental analyses of $16 \mathrm{~N}-11 \mathrm{P}-10 \mathrm{~K}$ and a micronutrient fertilizer of $12 \mathrm{Mg}-9 \mathrm{~S}-0.5 \mathrm{Cu}-8 \mathrm{Fe}-3 \mathrm{Mn}-1 \mathrm{Zn}$. Pre- and postplant applications of nitrogen $(\mathrm{N})$, phosphorus $(\mathrm{P})$, and potassium $(\mathrm{K})$, during the establishment year, were two and four times that applied for the controlled establishment treatment (Table 1). After the establishment year, all turfs received the same nutrition program and cultural practices.

The plots were irrigated six times daily at $2 \mathrm{~mm}$ per application until seedling emergence occurred. After seedling emergence, the turfs received $12 \mathrm{~mm}$ of irrigation daily for 4 weeks split among three applications. Subsequently, the turfs were irrigated with $50 \mathrm{~mm}$ per week until the growing season ended. After the establishment year, turfs were irrigated at $80 \%$ of potential evapotranspiration for the remainder of the study.

After the establishment year, management practices applied to the putting greens did not differ and were maintained according to regional recommendations for golf course putting greens (R. E. Gaussoin, personal communication). Plots were mowed six to seven times weekly at $0.32 \mathrm{~cm}$ and clippings were removed. Annual fertility applications of $29 \mathrm{~N}, 19.5 \mathrm{P}$, and $29 \mathrm{~K} \mathrm{~g} \cdot \mathrm{m}^{-2}$ were applied for the duration of the study. Management practices included sand top-dressing as follows: light sand top-dressing applications every 10 to $14 \mathrm{~d}$ based on turfgrass growth rate at $4.9 \times 10^{-4} \mathrm{~m}^{3} \mathrm{sand} / \mathrm{m}^{-2}$ per application and combined with vertical mowing before the top-dressing application; and heavy sand top-dressing applied twice annually (i.e., spring and fall) at $1.96 \times 10^{-3} \mathrm{~m}^{3}$ sand $/ \mathrm{m}^{-2}$ per application and combined with hollowtine core cultivation before each application. Core cultivation was performed with $1.6-\mathrm{cm}$ o.d. hollow tines to a 7.6-cm depth and 5.0$\mathrm{cm}$ spacing. Cores were removed after cultivation and before top-dressing. The same top-dressing sand was used throughout the study.

For Study 1, soil cores were collected for soil test analysis on 20 Oct. 2001 from all USGA-specification putting greens to 15.2$\mathrm{cm}$ depth or greater and partitioned into 0 - to $7.6-\mathrm{cm}$ and $7.6-$ to $15.2-\mathrm{cm}$ depths. On 25 Mar. 2004, soil cores were taken from all USGA-specification putting greens to a depth of $23 \mathrm{~cm}$ and, based on findings in the first study, were partitioned into 0 - to $2.5-\mathrm{cm}, 2.5$ to $10.2-\mathrm{cm}$, and $10.2-$ to $23.0-\mathrm{cm}$ depths for Study 2. In Study 3, cores were collected on 15 July 2004 from all USGA-specification putting greens to a depth of $21 \mathrm{~cm}$ and, based on results from the first two studies, were separated into mat and original root zone regions rather than arbitrary soil sampling depths. Soil cores were cut $\approx 1.25 \mathrm{~cm}$ above and below the respective visible interface to ensure that no original root zone material was included in the mat region and vice versa. For all studies, soil samples were obtained using a $2.54-\mathrm{cm}$ o.d. soil probe. Thatch was removed and discarded using a thin (less than 1-mm thick) serrated knife. In all studies, soil cores were laid side by side and partitioned by depth (Studies 1 and 2), or root zone region (Study 3) using the same serrated knife. Samples of $100 \mathrm{~g}$ soil (dry weight) were obtained at each depth or root zone region for each treatment plot. Soil samples were air-dried before chemical analysis.

Table 1. Establishment year treatments on U.S. Golf Association greens at John Seaton Anderson Turfgrass Research Facility near Mead, NE, from 1997 to 2000.

\begin{tabular}{|c|c|c|c|c|c|c|c|c|}
\hline \multirow[b]{4}{*}{ Applications } & \multicolumn{8}{|c|}{ Establishment treatment } \\
\hline & \multicolumn{4}{|c|}{ Accelerated } & \multicolumn{4}{|c|}{ Controlled } \\
\hline & $\overline{\mathrm{N}^{2}}$ & $\mathrm{P}$ & $\mathrm{K}$ & Micronutrient $^{\mathrm{y}}$ & $\mathrm{N}$ & $\mathrm{P}$ & $\mathrm{K}$ & Micronutrient \\
\hline & $--\cdot$ & $-\cdots$ & ---- & 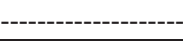 & --- & - & & 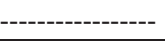 \\
\hline Preplant $^{\mathrm{x}}$ & 30 & 6.6 & 16.6 & 80 & 15 & 3.3 & 8.3 & 55 \\
\hline Postplant $^{\mathrm{w}}$ & 24 & 16.8 & 15.3 & 11.5 & 6 & 4.2 & 3.8 & 7 \\
\hline Total $^{\mathrm{v}}$ & 54 & 23.4 & 31.9 & 91.5 & 21 & 7.5 & 12.1 & 62 \\
\hline
\end{tabular}

${ }^{\mathrm{z}}$ Amounts are actual nitrogen, phosphorus, and potassium.

${ }^{\mathrm{y}} \mathrm{Micronutrient}$ fertilizer with analysis $12 \mathrm{Mg}-9 \mathrm{~S}-0.5 \mathrm{Cu}-8 \mathrm{Fe}-3 \mathrm{Mn}-1 \mathrm{Zn}$.

${ }^{x}$ Preplant was incorporated into upper $8 \mathrm{~cm}$ of the root zone before seeding. Analyses for fertilizer sources applied were $16 \mathrm{~N}-11 \mathrm{P}-10 \mathrm{~K}, 15 \mathrm{~N}-0 \mathrm{P}-24 \mathrm{~K}, 38 \mathrm{~N}-0 \mathrm{P}-$ $0 \mathrm{~K}$ and a micronutrient fertilizer.

${ }^{\text {w }}$ Postplant fertilizers applied during the growing season at full-rate weekly for accelerated and half-rate biweekly for controlled. Elemental analyses for fertilizers applied were $16 \mathrm{~N}-11 \mathrm{P}-10 \mathrm{~K}$ and a micronutrient fertilizer.

vTotal application amounts during the establishment year. 
Samples were analyzed for $\mathrm{pH}_{1: 1}$ (McLean, 1982), electrical conductivity for total soluble salts (Rhoades, 1982); organic matter (OM) by loss-on-ignition (Schnitzer, 1982); nitrate-nitrogen $\left(\mathrm{NO}_{3}-\mathrm{N}\right)$ by flow injection analysis (Knepel, 2003; Ruzicka and Hansen, 1988); Bray-P1 (P) (Bray and Kurtz, 1945), K, calcium (Ca), magnesium $(\mathrm{Mg})$, and sodium $(\mathrm{Na})$ by ammonium acetate extractable (Brown and Warncke, 1988); sulfur by calcium phosphate extractable (Helrich, 1990); zinc, iron (Fe), manganese, and copper by DTPA extractable (Lindsay and Norvell, 1978); and boron by hot water extractable (Berger and Truog, 1939). The CEC of each sample was obtained by summing the ammonium acetate exchangeable cations (Soil Survey Laboratory Staff, 1992).

Data were analyzed using analysis of variance with SAS version 8 (Statistical Analysis System; SAS Institute Inc., Cary, NC)
PROCMIXED procedure. Means were separated using Fisher's protected least significant difference multiple comparisons technique at $P=0.05$ (Dowdy and Wearden, 1991).

\section{Results and Discussion}

Study 1. Ten of the 16 nutrient and chemical properties investigated were observed to be significant in at least one two-way interaction involving putting green age, treatment, or sampling depth (Table 2). Three-way interactions were not relevant to the objectives of this study and therefore were omitted from this discussion (Table 2).

Nutrient concentrations and chemical properties were generally increased for all putting greens at the 0 - to $7.6-\mathrm{cm}$ depth compared with the $7.6-$ to $15.2-\mathrm{cm}$ depth (Tables 3 and 4). As putting greens age, $\mathrm{OM}$ accumulates in the upper part of the root zone as a result of plant and microbial buildup (Beard, 1973; Carrow, 2003; Curtis and Pulis, 2001; Habeck and Christians, 2000). Increased nutrient retention at the 0to 7.6-cm depth was likely the result of higher organic matter content and a subsequent increased CEC near the putting green surface. As putting greens increased in age, nutrient and chemical properties generally increased at the 0 - to $7.6-\mathrm{cm}$ depth, except for iron values, which were decreased at this depth in older greens (Table 4). Putting green age had little effect on nutrient or chemical properties at the $7.6-$ to $15.2-\mathrm{cm}$ root zone depth (Table 4). Results from this study were consistent with those found by McClellan et al. (2007) in which only P remained significantly higher beyond the establishment year for treatments receiving the accelerated grow-in procedure. Phosphorus is known to be relatively insoluble even in sand-based root zones (Beard,

Table 2. Analysis of variance for nutrients and chemical properties at two depths (Study 1), three depths (Study 2), and by root zone region (Study 3 ) in root zones of U.S. Golf Association specification putting greens. ${ }^{2}$

\begin{tabular}{|c|c|c|c|c|c|c|c|c|c|c|c|c|c|c|c|c|c|}
\hline \multicolumn{18}{|c|}{ Study $1^{y}$} \\
\hline Source & $\mathrm{df}$ & $\mathrm{NO}_{3}-\mathrm{N}$ & $\mathrm{P}$ & $\mathrm{K}$ & $\mathrm{Ca}$ & $\mathrm{Mg}$ & $\mathrm{S}$ & $\mathrm{Zn}$ & $\mathrm{Fe}$ & $\mathrm{Mn}$ & $\mathrm{Cu}$ & B & $\mathrm{pH}$ & $\mathrm{Na}$ & TSS & $\mathrm{CEC}$ & $\mathrm{OM}$ \\
\hline Putting green age ${ }^{\mathrm{x}}$ & 3 & $* *$ & NS & $*$ & $* *$ & $* *$ & $*$ & $* * *$ & $* * *$ & $* * *$ & $* * *$ & $* * *$ & * & $*$ & NS & $* *$ & $* * *$ \\
\hline Treatment $^{\mathrm{w}}$ & 3 & $* *$ & $* * *$ & $* * *$ & NS & NS & $* * *$ & $* *$ & $* * *$ & $* * *$ & $* * *$ & $* *$ & NS & NS & NS & NS & $* * *$ \\
\hline Age $\times$ treatment & 9 & $* *$ & NS & NS & NS & $* *$ & $* * *$ & NS & $* * *$ & NS & NS & NS & NS & NS & NS & NS & NS \\
\hline Depth & 1 & $* * *$ & $* * *$ & $* * *$ & $* * *$ & $* *$ & $* * *$ & $* * *$ & $* * *$ & $* * *$ & $* * *$ & $* * *$ & $* *$ & $*$ & $*$ & $* * *$ & $* *$ \\
\hline Age $\times$ depth & 3 & $*$ & $*$ & NS & NS & NS & NS & $* * *$ & $* * *$ & $* *$ & $*$ & $* * *$ & NS & NS & NS & NS & $* *$ \\
\hline Treatment $\times$ depth & 3 & $*$ & $* *$ & NS & NS & NS & $*$ & $* *$ & * & $*$ & $* *$ & NS & NS & NS & NS & NS & NS \\
\hline Age $\times$ treatment $\times$ depth & 9 & $* *$ & NS & NS & NS & NS & NS & NS & NS & NS & NS & NS & NS & NS & NS & NS & NS \\
\hline Replication total (age) $^{\mathrm{v}}$ & 40 & & & & & & & & & & & & & & & & \\
\hline Residual & 24 & & & & & & & & & & & & & & & & \\
\hline Total & 95 & & & & & & & & & & & & & & & & \\
\hline
\end{tabular}

Total

Source
Putting green age
Treatment
Age $\times$ treatment
Depth
Age $\times$ depth
Treatment $\times$ depth
Age $\times$ treatment $\times$ depth
Replication total $($ age $)$
Residual
Total

\begin{tabular}{|c|c|c|c|c|c|c|c|c|c|c|c|c|c|c|c|c|}
\hline \multicolumn{17}{|c|}{ Study $3^{\mathrm{t}}$} \\
\hline Source & $\mathrm{df}$ & $\mathrm{NO}_{3}-\mathrm{N}$ & $\mathrm{P}$ & $\mathrm{K}$ & $\mathrm{Ca}$ & $\mathrm{Mg}$ & $\mathrm{S}$ & $\mathrm{Zn}$ & $\mathrm{Fe}$ & $\mathrm{Mn}$ & $\mathrm{Cu}$ & B & $\mathrm{pH}$ & $\mathrm{Na}$ & TSS & $\mathrm{CEC}$ \\
\hline Putting green age & 3 & $*$ & $* *$ & $*$ & $* *$ & $* *$ & $* *$ & $* * *$ & $* *$ & $* *$ & $* * *$ & NS & NS & NS & NS & $* *$ \\
\hline Treatment & 3 & $*$ & $* * *$ & NS & NS & $*$ & $* * *$ & $*$ & $* *$ & $* * *$ & $* *$ & NS & NS & NS & NS & NS \\
\hline Age $\times$ treatment & 9 & NS & NS & NS & NS & NS & $* *$ & NS & NS & NS & NS & NS & NS & NS & NS & NS \\
\hline Rootzone & 1 & $* * *$ & $* * *$ & $* * *$ & $* * *$ & $* * *$ & $* * *$ & $* * *$ & $* *$ & $* * *$ & $* * *$ & $* * *$ & $* * *$ & $* *$ & $* * *$ & $* * *$ \\
\hline Age $\times$ rootzone & 3 & $* *$ & $* *$ & NS & NS & NS & NS & $* * *$ & $*$ & $* *$ & $* *$ & $*$ & NS & NS & NS & NS \\
\hline Treatment $\times$ rootzone & 3 & NS & $* * *$ & $* *$ & NS & $*$ & $* *$ & NS & NS & * & $*$ & NS & NS & NS & NS & NS \\
\hline Age $\times$ treatment $\times$ rootzone & 9 & NS & NS & NS & NS & NS & NS & NS & NS & NS & NS & NS & NS & NS & NS & NS \\
\hline Replication total (age) ${ }^{\mathrm{s}}$ & 40 & & & & & & & & & & & & & & & \\
\hline Residual & 24 & & & & & & & & & & & & & & & \\
\hline Total & 95 & & & & & & & & & & & & & & & \\
\hline
\end{tabular}

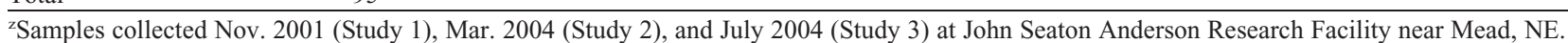

yStudy 1 conducted Nov. 2001. Depths include 0 to $7.6 \mathrm{~cm}$ and 7.6 to $15.2 \mathrm{~cm}$. Thatch was removed.

xPutting greens constructed sequentially from 1997 to 2000.

${ }^{w}$ Treatments were 2 (rootzone) $\times 2$ (establishment treatment) factorial. Rootzones were an 80:20 (v:v) sand and sphagnum peat mixture and an 80:15:5 (v:v:v) sand, sphagnum peat, and soil (Tomek silty clay loam) mixture. Establishment year treatments were an accelerated or controlled nutritional program.

${ }^{v}$ Variance components involving replications nested within putting green age were combined, and thus final model included only the total of all replications, including: replication (age), replication $\times$ treatment $($ age), and replication $\times$ depth (age).

uStudy 2 conducted Mar. 2004. Depths include 0 to $2.5 \mathrm{~cm}, 2.5$ to $10 \mathrm{~cm}$, and 10 to $20 \mathrm{~cm}$. Thatch was removed.

tStudy 3 conducted July 2004. Rootzones include accumulated mat region and underlying original root zone. Thatch was removed.

${ }^{s}$ Variance components involving replications nested within putting green age were combined, and thus final model included only the total of all replications, including: replication (age), replication $\times$ treatment (age), and replication $\times$ rootzone (age).

$\mathrm{TSS}=$ total soluble salts; $\mathrm{CEC}=$ cation exchange capacity; $\mathrm{OM}=$ organic matter.

$*, * *, * * *$ and NS indicate significant at the $P=0.05,0.01,0.001$, and nonsignificant, respectively. 
Table 3. Nutrient and chemical properties means at two depths (Study 1), three depths (Study 2), and by root zone region (Study 3) of U.S. Golf Association specification putting greens. ${ }^{z, y}$

\begin{tabular}{|c|c|c|c|c|c|c|c|c|c|c|c|c|c|c|c|c|}
\hline \multirow{2}{*}{$\begin{array}{l}\text { Study, rootzone depth } \\
\text { rootzone region }\end{array}$} & $\mathrm{NO}_{3}-\mathrm{N}$ & $\mathrm{P}$ & $\mathrm{K}$ & $\mathrm{Ca}$ & $\mathrm{Mg}$ & $\mathrm{S}$ & $\mathrm{Zn}$ & $\mathrm{Fe}$ & $\mathrm{Mn}$ & $\mathrm{Cu}$ & B & \multirow[t]{2}{*}{$\mathrm{pH}$} & $\mathrm{Na}$ & TSS & \multirow{2}{*}{$\begin{array}{c}\mathrm{CEC} \\
\left(\mathrm{cmol}_{\mathrm{c}} \cdot \mathrm{kg}^{-1}\right)\end{array}$} & \multirow{2}{*}{$\begin{array}{c}\mathrm{OM} \\
(\% / \mathrm{wt})\end{array}$} \\
\hline & \multicolumn{11}{|c|}{ 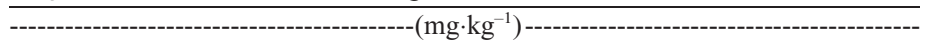 } & & \multicolumn{2}{|c|}{$\left(\mathrm{dS} \cdot \mathrm{m}^{-1}\right)$} & & \\
\hline 0 to $7.6 \mathrm{~cm}$ & 0.72 & 20.6 & 35.1 & 461.9 & 52.9 & 5.92 & 2.35 & 10.6 & 1.22 & 0.82 & 0.31 & 8.40 & 18.0 & 0.11 & 2.91 & 2.19 \\
\hline \multicolumn{17}{|l|}{ Study 2} \\
\hline 0 to $2.5 \mathrm{~cm}$ & 2.77 & 52.0 & 51.9 & 516.2 & 61.5 & 11.15 & 7.35 & 12.8 & 7.39 & 1.65 & 1.20 & 7.23 & 20.4 & 0.17 & 3.32 & $\mathrm{ND}^{\mathrm{v}}$ \\
\hline 2.5 to $10 \mathrm{~cm}$ & 1.40 & 17.6 & 23.0 & 371.8 & 43.6 & 7.35 & 2.53 & 10.0 & 2.54 & 0.84 & 0.77 & 7.58 & 10.4 & 0.07 & 2.33 & ND \\
\hline \multicolumn{17}{|l|}{ Study 3} \\
\hline Mat region & 6.17 & 64.4 & 33.3 & 460.7 & 66.4 & 7.69 & 5.59 & 11.0 & 4.59 & 1.41 & 0.81 & 7.29 & 18.0 & 0.21 & 3.02 & ND \\
\hline Original rootzone & 1.64 & 15.6 & 17.3 & 304.4 & 51.3 & 5.40 & 1.00 & 9.9 & 1.15 & 0.37 & 0.44 & 7.44 & 14.5 & 0.09 & 2.05 & ND \\
\hline LSD $(0.05)$ & 0.30 & 1.6 & 3.8 & 19.8 & 1.7 & 0.41 & 0.18 & 0.6 & 0.14 & 0.11 & 0.03 & 0.05 & 1.8 & 0.01 & 0.11 & ND \\
\hline
\end{tabular}

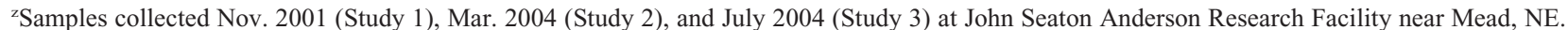

yPutting greens were constructed sequentially from 1997 to 2000.

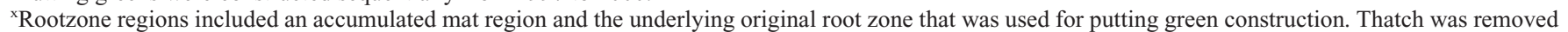
from all samples.

wFisher's protected least significant difference at the 0.05 level of probability.

'Not determined.

$\mathrm{TSS}=$ total soluble salts; $\mathrm{CEC}=$ cation exchange capacity; $\mathrm{OM}=$ organic matter.

1973; Lee et al., 2004; McCarty et al., 2003; Sartain and Brown, 1998; Turgeon, 1999; Turner and Hummel, 1992). Therefore, these results support the anticipated $\mathrm{P}$ retention in the root zone.

Study 2. Significant two-way interactions between putting green age and soil profile depth were observed for nutrient and chemical properties investigated, excluding $\mathrm{NO}_{3}-$ $\mathrm{N}$ and $\mathrm{Na}$ (Table 2). Three-way interactions, although rarely significant, were observed but were omitted from discussion because they were not relevant to the objectives of this study (Table 2).

Similar to results in Study 1, the upper compared with the lower root zone generally had higher levels of nutrients and chemical properties, except for $\mathrm{pH}$ (Tables 3 and 5). These results are consistent with previous research that investigated $\mathrm{P}$ and soil $\mathrm{pH}$ at the 0 - to $7.5-\mathrm{cm}, 7.5$ - to $15-\mathrm{cm}$, and $15-$ to 22.5 $\mathrm{cm}$ depths on a creeping bentgrass sandbased putting green (Branham et al., 2000). Branham et al. (2000) reported that $\mathrm{P}$ decreased while soil $\mathrm{pH}$ increased as soil sampling depth increased. Increased nutrient retention near the putting green surface in this study and for Branham et al. (2000) was likely the result of immobility of surfaceapplied $\mathrm{P}$ and increased CEC and nutrient supply associated with OM accumulation in the upper root zone. Reasons for reduced $\mathrm{pH}$ near the putting green surface may be explained by several contributing factors. First, the majority of microbial populations (Bigelow et al., 2000; Cooper, 1996; Mancino et al., 1993) and root mass (Beard, 1973; Carrow, 1993; Dernoeden, 2000; Murphy et al., 2005) is located in the upper few centimeters of the root zone profile. Microbial and root respiration releases $\mathrm{CO}_{2}$, which has been shown to increase soil acidity (Bigelow et al., 2000; Bunnell et al., 2000; Sparks, 2002; Tisdale and Nelson, 1956). Plant root uptake of cations such as $\mathrm{Ca}, \mathrm{Mg}$, $\mathrm{P}$, and $\mathrm{Fe}$ from soil exchange sites also results in reduced soil $\mathrm{pH}$ (Carrow et al., 2001; McCarty et al., 2003; Prasad and Power, 1997; Tisdale and Nelson, 1956). To absorb cations, roots excrete hydrogen ions in the form of organic acids, thus decreasing soil $\mathrm{pH}$ near the soil surface (McCarty et al., 2003). Additionally, microbial populations are largely responsible for nutrient transformations such as nitrification (Bigelow et al., 2000; Bunnell et al., 2000; Cooper, 1996) and sulfur oxidation (Cooper, 1996; Landschoot, 1998 ) that contribute to soil acidity (Carrow et al., 2001; Sparks, 2002; Tisdale and Nelson, 1956; Wortmann et al., 2003). Organic matter decomposition, which is higher near the putting green surface because of increased microbial activity and available $\mathrm{OM}$, may also contribute to the acidifying effect (Carrow et al., 2001; McCarty et al., 2003; Prasad and Power, 1997; Tisdale and Nelson, 1956). Another possibility for reduced soil $\mathrm{pH}$ in the upper root zone may be explained by sand dilution from topdressing material incorporated in the mat near the putting green surface. Branham et al. (2000) also cite that reduced soil $\mathrm{pH}$ at shallow root zone depths may be the result of the buffering capacity of $\mathrm{OM}$ in the acidic range.

Establishment treatment generally had no effect on nutrient and chemical properties studied except for $\mathrm{P}$, which remained higher for the accelerated establishment treatment at all depths and putting green ages (data not shown). Branham et al. (2000) reported increased $\mathrm{P}$ levels in sand-based putting greens root zones after only 1 to 2 years of fertilizer applications. Although $\mathrm{P}$ is relatively immobile in soils, its retention may have been further aided by alkaline $\mathrm{pH}$ conditions in the root zone (Beard, 1973; McCarty et al., 2003). Alkaline soil conditions, which were present in this study and the putting green root zones researched by Branham et al. (2000), lead to decreased P solubility in the root zone because high $\mathrm{pH}$ increases the tendency of $\mathrm{P}$ to form insoluble complexes with other soil elements (Beard, 1973; McCarty et al., 2003; Tisdale and Nelson, 1956).

Thirteen of the 16 nutrient and chemical properties investigated were influenced by the interaction of putting green age and sampling depth (Table 5). Many of these interactions were significant only at the $2.54-$ to $10.2-\mathrm{cm}$ depth. The $0-$ to $2.54-\mathrm{cm}$ depth was accumulated mat and the 10.2-to $20.4-\mathrm{cm}$ depth was the original root zone material. Because of varying mat development, however, samples at the 2.54- to 10.2$\mathrm{cm}$ depth were not uniform across putting green age because mat thickness for putting green ages $5,6,7$, and 8 years was $5.1,5.7$, 6.4 , and $7.0 \mathrm{~cm}$, respectively. Therefore, we speculate that mat development, which increased with putting green age, likely caused such significant interactions at the 2.54- to 10.2-cm depth. Beard (1973) and Carrow (2004) define mat as an organic zone, or layer, that is buried below the soil surface and comprised of partially decomposed thatch. Organic matter in the mat is intermixed with the top-dressing material (Beard, 1973; Carrow, 2004). Organic matter enhances nutrient retention and CEC in sand-based root zones (Beard, 1973; Bigelow et al., 2001; Callahan et al., 2001; Turgeon, 1999). As such, mat development and OM accumulation in our study likely contributed to the variability in nutrient retention at the 2.54 - to 10.2-cm sampling depth.

Study 3. Nearly all nutrient and chemical properties were affected by at least one twoway interaction (Table 2). Significant threeway interactions were not observed (Table 2). Partitioning root zone samples by region (mat versus original root zone) eliminated many of the interaction effects between putting green age and sampling depth that were evident in Studies 1 and 2 (Table 2). The accumulated mat region contained higher $\mathrm{CEC}, \mathrm{OM}$, and nutrient values, but lower $\mathrm{pH}$, than the 

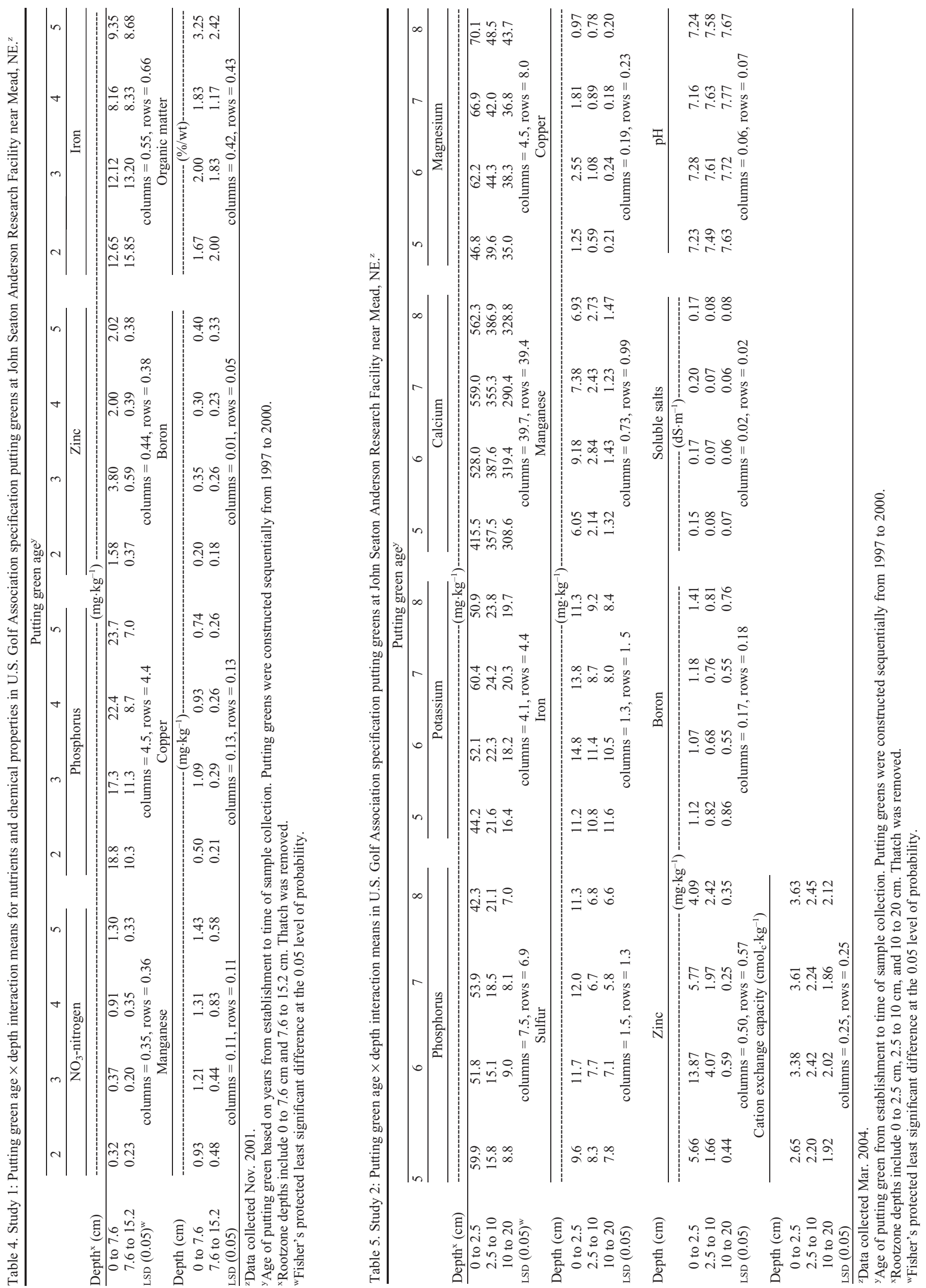
underlying original root zone for all greens (Table 3). Cation exchange capacity is enhanced by root zone OM content, and $\mathrm{CEC}$ values were likely greater in the mat region because OM content was higher in the mat (Beard, 1973; Bigelow et al., 2001; Callahan et al., 2001; Turgeon, 1999). Increased $\mathrm{OM}$ and CEC would contribute to increased nutrient retention and availability in the mat region when compared with the underlying original root zone. Soil $\mathrm{pH}$ was lower in the mat region for the same reasons described in Study 2. Although the mat region was very different in nutrient and chemical properties from the original root zone, neither mat nor original root zones were influenced by putting green age.

Summary. In summary, the 80:20 (sand: peat) root zone was generally not chemically different from the 80:15:5 (sand: peat: soil) for any of the three studies. Because root zone had minimal to no effect, replacing some of the peat with soil in the root zone could reduce construction costs and aid in nutrient retention given the soil-amended root zone meets USGA specifications. Establishment treatment had no effect beyond the establishment year except for increased $\mathrm{P}$ for greens that received the accelerated establishment treatment. As such, increased fertility inputs during the establishment year may not be environmentally responsible because the additional nutrient inputs were apparently not retained in the root zones under the conditions of this study. Guertal (2008) reported higher $\mathrm{N}$ leaching during the grow-in phase and for higher $\mathrm{N}$ application rates on sandbased putting green root zones in Alabama.

After the establishment year, CEC, soluble salts, OM, and all nutrients investigated generally decreased with depth, whereas $\mathrm{pH}$ increased with depth for all greens. As putting greens aged, OM accumulates near the root zone surface (Carrow, 1996, 2003; Carrow et al., 2001; Curtis and Pulis, 2001, Davis et al., 1990; Duble, 1996; Habeck and Christians, 2000). Organic matter enhances nutrient retention and $\mathrm{CEC}$ in sand-based root zones (Beard, 1973; Bigelow et al., 2001; Callahan et al., 2001; Turgeon, 1999). Organic matter accumulation in the upper region of the putting green root zones studied may have contributed to increased retention of nutrient and chemical properties near the putting green surface, particularly as the putting greens increased in age.

In studies involving multiple sampling depths, mat accumulation likely contributed to interaction effects between putting green age and sampling depth. Excluding $\mathrm{pH}$, all nutrient and chemical properties were higher in the mat versus the underlying original root zone. Although very different from each other, the mat and original root zone generally exhibit chemical uniformity within eachrespective root zone region for all putting green ages. With this in mind, sampling should account for the nutrient contribution associated from the mat and likely should not be averaged with sampling depths extending beyond the mat region.

\section{Literature Cited}

Alexander, M. 1977. Introduction to soil microbiology. 2nd Ed. Wiley, New York, NY.

Beard, J.B. 1973. Turfgrass science and culture. Prentice-Hall, Englewood Cliffs, NJ.

Beard, J.B. 2002. Turf management for golf courses. 2nd Ed. John Wiley and Sons, Inc., Hoboken, NJ.

Berger, K.C. and E. Truog. 1939. Boron determination in soils and plants. Ind. Eng. Chem. Anal. Ed. 11:540-545.

Bigelow, C.A., D.C. Bowman, and D.K. Cassel. 2001. Nitrogen leaching in sand-based rootzones amended with inorganic soil amendments and sphagnum peat. J. Amer. Soc. Hort. Sci. 126:151-156.

Bigelow, C.A., A.G. Wollum, and D.C. Bowman. 2000. Soil microbial populations in sand-based root zones. Golf Course Management. 68:6569.

Branham, B.E., E.D. Miltner, P.E. Rieke, M.J. Zabik and B.G. Ellis. 2000. Groundwater contamination potential of pesticides and fertilizers used on golf courses, p. 66-77. In: Clark, J.M. and M.P. Kenna (eds.). Fate and management of turfgrass chemicals. ACS Symposium Series 743. Amer. Chem. Soc., Washington, DC.

Bray, R.H. and L.T. Kurtz. 1945. Determination of total, organic, and available forms of phosphorus in soils. Soil Sci. 59:39-45.

Brown, J.R. and D. Warncke. 1988. Recommended cation tests and measures of cation exchange capacity, p. 15-16. In: Dahnke, W.C. (ed.). 1516. Recommended chemical soil test procedures for the North Central Region. North Dakota Agr. Exp. Stn. Bull

Bunnell, B.T., B. McCarty, and R. Dodd. 2000 Why is carbon dioxide bad for golf root zones? Elevated levels of carbon dioxide increase the acidity of roots. Golf Course Management. 68:63-67.

Callahan, L.M., R.S. Freeland, J.M. Parham, A.M. Saxton, R.D. von Bernuth, D.P. Shepard, and J.M. Garrison. 2001. Geotextiles as an intermediate layer in USGA and USGA-type greens. Agr. Exp. Station Bull. 699. Univ. of Tenn., Knoxville, TN.

Callahan, L.M., R.S. Freeland, J.M. Parham, R.D von Bernuth, D.P. Shepard, and J.M. Garrison. 1997. Geotextiles as substitute for choke layer sand in USGA greens. II. Particle migration and condition of separation layers. Intl. Turfgrass Soc. Res. J. 8(Part 1):75-86.

Carrow, R.N. 1993. Establishing bentgrass greens on sand-based greens. Golf Course Management. 61:90, 92-93, 96, 98.

Carrow, R.N. 1996. Summer decline of bentgrass greens. Golf Course Management. 64:51-56.

Carrow, R.N. 2003. Surface organic matter in bentgrass greens. USGA Turfgrass Environ. Res. Online. 2:1-12. 17 Aug. 2004. < http://turf. lib.msu. edu/tero/v02/n17.pdf>.

Carrow, R.N. 2004. Surface organic matter in bermudagrass greens: A primary stress? Golf Course Management. 72:102-105.

Carrow, R.N., D.V. Waddington and P.E. Rieke. 2001. Turfgrass soil fertility and chemical problems: Assessment and problems. Ann Arbor Press, Chelsea, MI

Cooper, R.J. 1996. It's dark down there: Soils teem with tiny organisms. Golf Course Management. 64:63-67.

Curtis, A. and M. Pulis. 2001. Evolution of a sandbased root zone. Golf Course Management. 69:53-56.

Davis, W.B., J.L. Paul, and D. Bowman. 1990. The sand putting green: Construction and manage- ment. Coop. Ext. Div. of Agr. and Nat. Resources. Pub. 21448. Univ. of California, Oakland, CA.

Dernoeden, P.H. 2000. Creeping bentgrass management. Ann Arbor Press, Cheslea, MI.

Dowdy, S. and S. Wearden. 1991. Statistics for research. 2nd Ed. Wiley and Sons, New York, NY.

Duble, R.L. 1996. Turfgrasses. 2nd Ed. Texas A\&M University Press, College Station, TX.

Gibbs, R.J. 2001. A review of the playing performance of artificial bowling greens. Proc. of the Inaugural New Zealand Sports Turf Conference and Trade Show. 1:130-134.

Guertal, E.A. 2008. USGA Turfgrass and Environmental Research Online 15 Mar. 7:1-6. 9 Feb. 2009. <http://usgatero.msu.edu/v07/n06.pdf $>$.

Habeck, J. and N. Christians. 2000. Time alters greens' key characteristics. Golf Course Management. 68:54-60.

Happ, K.A. 1995. Sampling for results: The methods are important. USGA Green Section Record. 33:1-4.

Helrich, K. (ed.) 1990. Official methods of analysis of the association of official analytical chemists. 11th Ed. AOAC, Inc., Arlington, VA. Method 980.02. p. 34.

Kerek, M., R.A. Driber, W.L. Powers, R.C. Shearman, R.E. Gaussoin, and A.M. Streich. 2002. Accumulation of microbial biomass within particulate organic matter of aging golf greens. Agron. J. 94:455-461.

Knepel, K. 2003. Determination of nitrate in 2M $\mathrm{KCl}$ soil extracts by flow injection analysis. QuikChem Method 12-107-04-1-B. Lachat Instruments, Loveland, $\mathrm{CO}$

Landschoot, P. 1998. Managing soil $\mathrm{pH}$ in turf Grounds Maint. 33:C36-37, C40, C42.

Lee, S.K., D.D. Minner, N.E. Christians, and H.G. Taber. 2004. Evaluation of phosphorus rate and mixing depth on the growth and establishment of Poa pratensis L. in sand-based systems. Iowa Turfgrass Res. Rep. p. 53-54. Iowa State University, Ames, IA.

Lewis, J.D. 2005. Soil physical properties of aging golf course putting greens. MS thesis. Univ. of Nebraska, Lincoln, NE.

Lindsay, W.L. and W.A. Norvell. 1978. Development of a DTPA soil test for zinc, iron, manganese, and copper. Soil Sci. Soc. Amer. J. 42:421-428.

Mancino, C.F., M. Barakat, and A. Maricic. 1993. Soil and thatch microbial populations in an 80 percent sand:20 percent peat creeping bentgrass putting green. HortScience 28:189-191.

McCarty, L.B., I.R. Rodriguez B.T. Bunnell, and F.C. Waltz. 2003. Fundamentals of turfgrass and agricultural chemistry. John Wiley and Sons, Inc., Hoboken, NJ.

McClellan, T.A., R.C. Shearman, R.E. Gaussoin, M. Mamo, C.S. Wortmann, G.L. Horst, and D.B. Marx. 2007. Nutrient and chemical characterization of aging golf course putting greens: Establishment and rootzone mixture treatment effects. Crop Sci. 47:193-199.

McLean, E.O. 1982. Soil pH and lime requirement, p. 199-224. In: Page, A.L., R.H. Miller and D.B. Keeney (eds.). Methods of soil analysis. Part 2. Agron Monogr. 9. ASA and SSSA, Madison, WI.

Moore, J. 2000. Good ol' USGA stands the test of time. Golfdom. 56:31-34, 37.

Murphy, J.A. 2003. Longer term assessment of putting green rootzone mixes under two microenvironments. Turfgrass Environ. Res. Summ. p. 2. United States Golf Association, Far Hills, NJ.

Murphy, J.A., H. Samaranayake, J.A. Honig, T.J. Lawson, and S.L. Murphy. 2005. Creeping 
bentgrass establishment on amended-sand root zones in two microenvironments. Crop Sci. 45:1511-1520.

Murphy, J.W., T.R.O. Field, and M.J. Hickey. 1993. Age development in sand-based turf. Intl. Turfgrass Soc. Res. J. 7(Part 1):464-468.

Prasad, R. and J.F. Power. 1997. Soil fertility management for sustainable agriculture. CRS Press, Boca Raton, FL.

Rhoades, J.D. 1982. Soluble salts, p. 167-179. In: Page, A.L., R.H. Miller and D.B. Keeney (eds.). Methods of soil analysis. Part 2. Agron. Monogr. 9. ASA and SSSA, Madison, WI.

Ruzicka, J. and E.H. Hansen1988. Flow injection analysis. 2nd Ed. John Wiley \& Sons, New York, NY.

Sartain, J.B. and E.A. Brown. 1998. Enhancement of phosphorus retention in USGA greens. Annu. Meet. Abstr. p. 129. ASA, CSSA, and SSSA, Madison, WI.
Schnitzer, M. 1982. Organic matter characterization, p. 581-594. In: Page, A.L., R.H. Miller and D.B. Keeney (eds.). Methods of soil analysis. Part 2. Agron. Monogr. 9. ASA and SSSA, Madison, WI.

Soil Survey Laboratory Staff. 1992. Soil survey laboratory methods manual. Soil Surv. Invest. Reps. 42. USDA-SCS, Washington, DC.

Sparks, D.L. 2002. Environmental soil chemistry. 2nd Ed. Academic Press, San Diego, CA.

St. John, R.A. and N. Christians. 2002. Turfgrass root zones: Supplemental calcium is not always necessary or desirable on calcareous sandbased putting greens. Golf Course Management. 70:97-100.

Tisdale, S.L. and W.L. Nelson. 1956. Soil fertility and fertilizers. The MacMillon Company, New York, NY.

Turgeon, A.J. 1999. Turfgrass management. 5th Ed. Prentice-Hall, Upper Saddle River, NJ.
Turner, T.R. and N.W. Hummel, Jr. 1992. Nutritional requirements and fertilization, p. 385-439. In: Waddaington, D.V., R.N. Carrow, and R.C. Shearman (eds.). Turfgrass. Agronomy Monograph No. 32. Amer. Soc. Agron., Madison, WI.

USGAGreen Section Staff, 1993. USGA recommendations for a method of putting green construction. USGA Green Section Record. 31:1-33.

Waddington, D.V.1992. Soils, soil mixtures, and soil amendments, p. 331-383. In: Waddington, D.V., R.N. Carrow, ans R.C. Shearman (eds.) . Turfgrass. Agronomy Monograph No. 32. Amer. Soc. Agron., Madison, WI.

Witteveen, G. and M. Bavier. 1998. Practical golf course maintenance. Ann Arbor Press, Chelsea, MI.

Wortmann, C., M. Mamo, and C. Shapiro. 2003. Management strategies to reduce the rate of soil acidification. NebGuide G03-1503-A. Coop. Ext., Univ. of Nebraska, Lincoln, NE. 